\title{
ABOUT THE FORMATION OF Camellia sinensis (L.) O. Kuntze RESISTANCE UNDER INSUFFICIENT WATER SUPPLY AT THE ROOT FERTILIZATION WITH CALCIUM CLAY
}

\section{L.S. MALYUKOVA, Z.V. PRITULA, N.V. KOZLOVA, V.V. KERIMZADE, A.V. VELIKII}

All-Russian Research Institute of Floriculture and Subtropical Crops, Federal Agency of Scientific Organizations, 2/28, ul. Yana Fabriciusa, Sochi, 354002 Russia, e-mail MalukovaLS@mail.ru

Received July 19, 2016

\section{Abstract}

In the conditions of Russian Black Sea coast and in many other regions of the world (China, India) tea plant is faced with seasonal water shortages leading to a significant loss of productivity according to different authors, up to 40-50 \% (M. Mukhopadhyay et al., 2014; L.S. Malyukova, 2014). In this regard, physiological and biochemical mechanisms of tea plant resistance to water shortages as well as the effectiveness of various exogenous inducers are being researched; more drought-resistant cultivars are being searched for the breeding. Considerable interest in research is related to the study of application of exogenous calcium, which is a mediator in signaling within the cell when there is a synthesis of stress proteins, which, in turn, provide the resistance to adverse environmental factors, as well as the subsequent exit from this state (X.Y. Gao et al., 1999; M.Y. Shu et al, 2000). The papers showed calcium effect on reducing oxidative damage in various plants (including tea plant) at drought by inducing antioxidant system (X.Y. Gao et al., 1999; M. Lee et al, 2004; S.S. Medvedev, 2005; H. Upadhyaya et al., 2012; E.G. Rikhvanov et al., 2014). In Russia, it is the first time when in a field experiment we studied an effect of root fertilization with calcium on the functional state of tea plants and the mode of their nutrition at low water supply. Calcium was introduced into the soil in the form of a natural fertilizer (clay and lime matter containing $40 \%$ of $\mathrm{CaO}$ ) at $100 \mathrm{~kg} \mathrm{CaO}$ per ha along with macronutrients $\left(\mathrm{N}_{240} \mathrm{P}_{70} \mathrm{~K}_{90}\right)$ against solely $\mathrm{N}_{240} \mathrm{P}_{70} \mathrm{~K}_{90}$ in control. During summer periods of high moisture deficit (late July to August) we studied the dynamics of catalase activity in mature leaves and 3-leaf fleshes, $\mathrm{pH}$ of the cell sap, water supply and water loss, as well as chemical composition of plants and soil. It was found that under the influence of calcium in the stressful period there were an increase in catalase activity in mature leaves (by $10-19 \mathrm{ml}$ of $\mathrm{O}_{2} / \mathrm{g}$ within $3 \mathrm{~min}$ at different periods), a reduction of water loss (on average by $20 \%$ ), a lesser alkalescency of the cell sap (by 0.05-0.07 units), and a significant (by 27-33\%) increase in plant productivity, which indicates more stable functional state both during water stress and rehydration. Catalase activity in shoots (to a lesser extent in mature leaves) correlated with the $\mathrm{pH}$ of the cell sap ( $r=0.93$ and $r=0.53$, respectively), which determined its important role in the formation of tea plant oxidative state. More adapted restructuring of the plants to extreme conditions and their subsequent effective recovery was due to the effect of calcium fertilizers on the cation-exchange capacity of soil absorbing complex, i.e. 1.5-3-fold enhancing the calcium exchange, while maintaining the potassium status and subsequent coordinated absorption of major biogenic nutrient elements, which provides preferential flow of potassium and calcium in plants as compared to nitrogen and phosphorus.

Keywords: tea plant, Samellia sinensis (L.) O. Kuntze, drought resistance, calcium, mineral fertilizers, enzyme activity, water loss, $\mathrm{pH}$ of the cell sap, agrochemical properties of soils, chemical composition of leaves

In the conditions of Russian Black Sea coast and in many other regions of the world (China, India) tea plant is faced with seasonal water shortages leading to a significant loss of productivity (up to 40-50 \%) [1-5]. Long-term periods of insufficiency of water supply represent the most harmful factor for plants, especially for perennial plants, due to oxidative stress with production of active oxygen forms $[6,7]$. Thus, research on effectiveness of various exogenous inducers in terms of perennial plants drought resistance regulation is considered to be an up-to-date line of research both worldwide [7-10] and in Russia [11-13]. Calci- 
um [14-17], acting as a universal second messenger [18-21] for enhancement in synthesis of stress proteins and other compounds [22-25] ensuring resistance of plants to adverse environmental factors with subsequent reversal of this state, is considered as one of the most effective inducers. The papers showed calcium effect on reducing oxidative damage in various plants (including tea plant) at drought by inducing antioxidant system [7, 14-18]. Resistance to oxidative stress is assessed through a wide range of plants functional state indicators (antioxidant enzymes, photosynthetic pigments, low molecular weight antioxidants, stress proteins, water status, productivity as an integral indicator, etc.) [13-17, 26]. The data on a number of annual crops and some perennial crops, including tea plant, has been obtained; however, effectiveness of root application of calcium fertilizers in tea plantations of the world's most northern subtropical areas (Russian Black Sea coast), where recurrent droughts are an issue of particular concern, is still not fully understood. This gap in our knowledge can be filled with the studies presented in this work.

The purpose of this study is to assess the effect of root application of calcium on functional state of tea plant and to identify the characteristics of pool formation and biogenic elements uptake under the moisture deficit conditions in the context of nonspecific antioxidant protection.

Techniques. The microplot field experiment was conducted in a Colchis tea plantation (planted in 1983) (the city of Sochi, the settlement of Dagomys, 2013-2015). A natural fertilizer, i.e. a clay and lime matter containing $40 \%$ of $\mathrm{CaO}$, introduced into the surface soil at a dose of $100 \mathrm{~kg} \mathrm{CaO}$ per hectare along with macronutrients $\mathrm{N}_{240} \mathrm{P}_{70} \mathrm{~K}_{90}$ against solely $\mathrm{N}_{240} \mathrm{P}_{70} \mathrm{~K}_{90}$ in control, was used as an exogenous calcium source. The plot area was $10 \mathrm{~m}^{2}$, application in 3 replicates was used on acid brown forest soil. The studies were performed during the most stressful summer periods as to water supply (late July-August), characterized by absence of precipitation or intermittent precipitation. Soil (depth of $0-20 \mathrm{~cm}$ ) and plant (3-leaf fleshes and mature 5-6 month leaves) samples were taken progressively.

The following parameters were evaluated in plant samples: catalase activity as per I.I. Gunar [27], cell sap concentration by refractometry as per L.A. Filippov [28]; pH of cell sap by potentiometry, water retention capacity by modified Arland's wilting method [27]; water loss was calculated as the ratio between water loss by leaves during a drought period and initial fresh weight of a leaf [29]. Accelerated acid digestion method as per K.E. Ginzburg et al. [30] with subsequent application of standard procedures was used for macro-element analysis of leaves. The following parameters were evaluated in soil samples: $\mathrm{pH}$ of ${ }_{\mathrm{KCl}}$ by potentiometry, $\mathrm{Ca}^{2+}$ and $\mathrm{Mg}^{2+}$ by trilonometry, ammonia nitrogen by spectrophotometry, labile phosphorus and potassium (as per Oniani) by spectrophotometry, field moisture by weight method [31].

AGROCHEMISTRY software for mineral fertilizers effect modeling (All-Russia Research Institute of Agrochemistry, Russia) was used for data processing by variation and descriptive statistics methods [32].

Results. August 2014 was characterized by precipitation deficit $(13.0 \mathrm{~mm})$ and high average daily air temperature, i.e. $25.4{ }^{\circ} \mathrm{C}$ with the maximum up to $33{ }^{\circ} \mathrm{C}$. Soil moisture content amounted to 30-35\% (early August), cell sap concentration - to 8.1-8.6\% which approximated the critical value $(9 \%)$, indicating disruption of the water regime. In 2015 precipitation deficit was observed as early as in July $(61.5 \mathrm{~mm})$, with an increase in August $(15.0 \mathrm{~mm})$ due to high average daily air temperature $\left(24.2-25.7{ }^{\circ} \mathrm{C}\right.$ with the maximum up to $32{ }^{\circ} \mathrm{C}$ ), which lead to decrease in soil moisture content up to $20 \%$. Under these conditions cell sap concentration amounted to $10 \%$ as early as in July, and to $13 \%$ 
in mid-August, indicating severe disruption of tea plant water supply which lead to decrease in sprout formation. Catalase (antioxidant enzyme) activity (CA) in mature leaves of tea plant in these stressful conditions was rather high (Fig. 1) and far exceeded the value in favorable conditions [12], which is the first indication of oxidative stress, as the enzyme, along with other compounds, plays a key role in regulation of reactive oxygen intermediates content [7, 16-18, 22, 33].

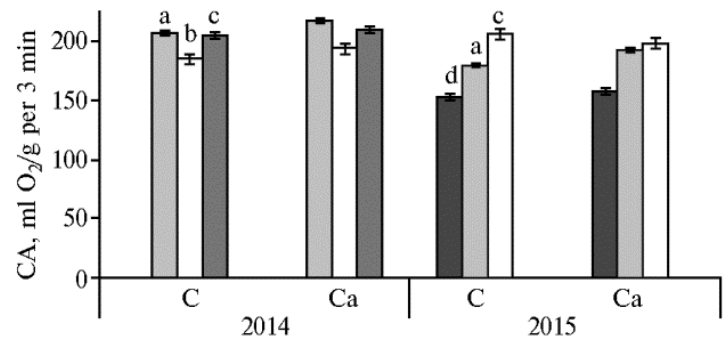

Fig. 1. Catalase activity (CA) in mature leaves of Colchis tea plant [Camellia sinensis (L.) 0 . Kuntze] under root application of calcium during water stress periods: $\mathrm{a}-$ August 04, b - August 19, c - August 27 , d - July 27; C - control (microplot field experiment, the city of Sochi).

The use of a calcium fertilizer during all periods (except for August 19, 2015) resulted in a significant increase in catalase ac-

tivity in mature leaves, indicating more effective functioning of a signaling intracellular network, where oxidative and calcium pathways are closely connected [14-17]. This is consistent with the data on reduced oxidative damage at drought in case of foliar calcium application in tea plantations due to induction of antioxidant system of a plant $[3,7]$.

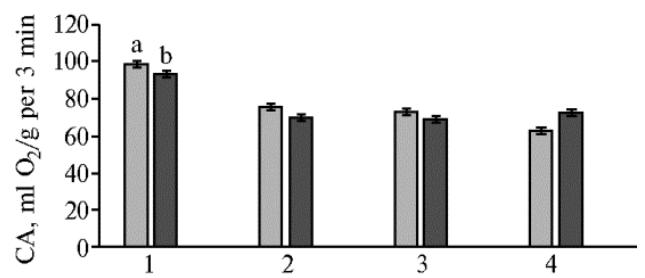

Fig. 2. Catalase activity (CA) in 3-leaf fleshes of Colchis tea plant [Camellia sinensis (L.) 0 . Kuntze] under root application of calcium during water stress periods: $\mathrm{a}-$ control, $\mathrm{b}-\mathrm{Ca} ; 1-$ May, 2 - July, 3 - August decade I, 4 August decade II (microplot field experiment, the city of Sochi, 2015).

Catalase activity of a tea plant fresh shoot (3-leaf fleshes) was significantly lower than that of mature leaves (Fig. 2). It was also observed by other researchers and is associated with more pronounced photostress, high degree of water loss comparing with other leaves, and with the age of a leaf [34]. During vegetation period the enzyme activity was decreasing from May (optimal conditions in terms of water supply) till August (moisture deficit) which correlated with the water loss in leaves $(r=-0.59$ for cell sap concentration). Insignificant calcium effect was observed in this part of tea plant (fresh growing shoot) only during the increased stress period (August decade II).

Cell sap concentration of fleshes (to a lesser extent in mature leaves) correlated with $\mathrm{pH}$ of the cell sap $(r=0.93$ and $r=0.53$, respectively), which determined its regulatory function in the formation of tea plant oxidative state. At that, increase in $\mathrm{pH}$ of the cell sap under conditions, causing accelerated transpiration (significant moisture vapor pressure deficit in air, high light intensity and leaf temperature), triggers the stomatal closure mechanism by means of modulation of abscisic acid concentration [35]. In case of calcium application this indicator was different from control (by $0.05-0.07 \mathrm{pH}$ units) during the whole stressful period in 2015 (except for August 27), which confirmed the wellknown role of $\mathrm{Ca}$ in stomatal function regulation $(35,36)$.

With onset of air and soil drought in August and September (air moisture of $70-71 \%$, soil field moisture of $20 \%$; for reference: in July, under relatively normal water supply conditions, these are 75-79 and 30\%, respectively) water loss under $\mathrm{Ca}$ application was significantly lower $(88 \%)$ than that in control 
(106\%), indicating greater water retention capacity of plant cells. With regard to solids content in mature leaves (34.9\% against $36.5 \%$ in control) and 3-leaf fleshes (22.6-25.5\% against 23.1-26.9\% in control), some increase in water supply under stressful conditions was observed as well. During several years, positive effect of $\mathrm{Ca}$ application was found on yield which is considered as an integral indicator of plants functioning under extreme conditions and during poststress recovery (Fig. 3).

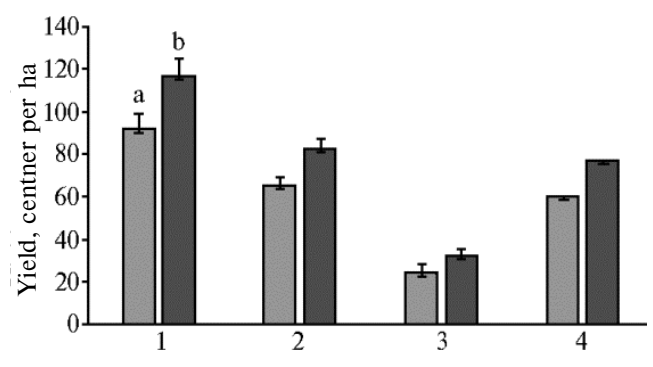

Fig. 3. Colchis tea plantation productivity [Camellia sinensis (L.) O. Kuntze] by years of observation under root application of calcium during water stress periods: $\mathrm{a}-$ control, $\mathrm{b}-$ Ca; 1,2 and $3-2013,2014$ and 2015, respectively, 4 - average (microplot field experiment, the city of Sochi).

The changes in physiological functions under stress are directly related to nutrition regime. In our experiments, general reduction of ammonia

nitrogen and labile phosphorus and potassium content in soil adsorption complex was observed with increase of drought (in case of soil moisture decrease from 30 to $20 \%$ ), with simultaneous increase in calcium content (Table 1). At calcium fertilizers application, an increase in calcium and magnesium ions and decrease in ammonia nitrogen and phosphate ions was observed in the soil adsorption complex structure, as compared to control.

1. Mineral nutrients content in the tea plantation soil (Colchis tea) under root application of calcium during water stress periods $(X \pm x$, microplot field experiment, the city of Sochi, 2015)

\begin{tabular}{|c|c|c|c|c|c|}
\hline \multirow{2}{*}{ Variant } & \multicolumn{3}{|c|}{ Content, $\mathrm{mg} / \mathrm{kg}$} & \multicolumn{2}{|c|}{ Content, mmol-equivalent/100 g } \\
\hline & $\mathrm{NH}_{4}^{+}$ & $\mathrm{P}_{2} \mathrm{O}_{5}$ & $\mathrm{~K}_{2} \mathrm{O}$ & $\mathrm{Ca}^{2+}$ & $\mathrm{Mg}^{2+}$ \\
\hline \multicolumn{6}{|c|}{ August 4} \\
\hline Control & $52 \pm 2.7$ & $870 \pm 13.0$ & $310 \pm 4.4$ & $1.6 \pm 0.4$ & $2.7 \pm 0.5$ \\
\hline $\mathrm{Ca}$ & $89 \pm 3.5$ & $720 \pm 23.2$ & $320 \pm 4.4$ & $3.0 \pm 0.6$ & $3.9 \pm 0.7$ \\
\hline \multicolumn{6}{|c|}{ August 30} \\
\hline Control & $45 \pm 1.5$ & $960 \pm 10.7$ & $270 \pm 8.8$ & $1.4 \pm 0.2$ & $2.4 \pm 0.6$ \\
\hline $\mathrm{Ca}$ & $64 \pm 0.9$ & $590 \pm 34.6$ & $320 \pm 6.5$ & $4.5 \pm 0.7$ & $4.2 \pm 0.8$ \\
\hline
\end{tabular}

When $\mathrm{Ca}$ application, nitrogen accumulation in leaves was predominantly observed in the beginning of stressful period, while with increase of stress calcium and potassium accumulation took place at the expense of nitrogen (Table 2). Decrease in nitrogen and magnesium content with increased calcium and potassium content in leaves indicated restructuring of cell metabolism toward reduced assimilation for more effective functioning under stress and during poststress rehydration. The amount of $\mathrm{Ca}^{2+}$ in cytosol induces antioxidant system of plants and regulates one of potassium channels in a cell, ensuring increase in $\mathrm{K}^{+}$ concentration, which leads to increased cytoplasm viscosity and, as a result, cell stability [35-37].

2. Chemical composition of a mature leaf ( $\%$ of dry weight) of Colchis tea plant [Camellia sinensis (L.) O. Kuntze] under root application of calcium during water stress periods $(X \pm x$, microplot field experiment, the city of Sochi, 2014-2015)

\begin{tabular}{l|c|c|c|c|c}
\hline \multicolumn{1}{c}{ Variant } & $\mathrm{N}$ & $\mathrm{P}_{2} \mathrm{O}_{5}$ & $\mathrm{~K}_{2} \mathrm{O}$ & $\mathrm{CaO}$ & $\mathrm{MgO}$ \\
\hline Control & $3.37 \pm 0.01$ & $0.66 \pm 0.02$ & A u u t 4 \\
$\mathrm{Ca}$ & $3.44 \pm 0.02$ & $0.69 \pm 0.02$ & $2.05 \pm 0.02$ & $0.90 \pm 0.01$ & $0.72 \pm 0.02$ \\
Control & $2.98 \pm 0.01$ & $0.72 \pm 0.01$ & $2.12 \pm 0.02$ & $0.90 \pm 0.02$ & $0.60 \pm 0.01$ \\
$\mathrm{Ca}$ & $2.24 \pm 0.03$ & $0.70 \pm 0.01$ & $2.61 \pm 0.05$ & $0.80 \pm 0.01$ & $0.72 \pm 0.03$ \\
\hline
\end{tabular}


Thus, root application of calcium led to an increased resistance of tea plants to insufficient water supply. This was manifested by higher catalase activity of leaves $\left(+10-19 \mathrm{ml} \mathrm{O}_{2} / \mathrm{g}\right.$ per $3 \mathrm{~min}$ ), a decreased water loss (by $20 \%$ in average) and $\mathrm{pH}$ of the cell sap, and an increased yield of green tea leaves $(+2000-$ $3000 \mathrm{~kg} / \mathrm{ha}$ on average). These effects were due to changes in cation composition of soil adsorption complex (toward 1.5-3-fold increase in calcium content at unchanged potassium content) and increase in potassium and calcium uptake by plants as influenced by calcium fertilizers. Therefore, these fertilizers ensured resistance to oxidative stress and contributed to further post-stress plant recovery via changes in chemical composition of plants and, as a result, in intracellular concentration of elements.

\section{REFEREN C ES}

1. Bhagat R.M., D e b B a ruah R., C a c i que S. Climate and tea [Camellia sinensis (L.) O. Kuntze] production with special reference to north eastern India: a review. Journal of Environmental Research and Development, 2010, 4(4): 1017-1028.

2. B a r u a h 1 R.D., B h a g a t R.M. Climate trends of Northeastern India: a long term pragmatic analysis for tea production. Two and a Bud, 2012, 59(2): 46-49.

3. Upadhy ay a H., Pand a S.K. Abiotic stress responses in tea [Camellia sinensis (L.) O. Kuntze]: An overview. Reviews in Agricultural Science, 2013, 1: 1-10 (doi: 10.7831/ras.1.1).

4. Mukhopadhy a M., Mondal T.K. The physio-chemical responses of Camellia plants to abiotic stresses. J. Plant Sci., 2014, 1: 1-12.

5. M ly k k va L.S. Plodovodstvo i yagodovodstvo Rossii, 2014, 38(1): 255-261 (in Russ.).

6. Damayanthi M.M.N., Mohotti 1 A.J., N is s a nka S.P. Comparison of tolerant ability of nature field grown tea (Camellia sinensis L.) cultivars exposed to a drought stress in Passara Area. Tropical Agricultural Research, 2010, 22(1): 66-75 (doi: 10.4038/tar.v22i1.2671).

7. U padhy y a H., D u t a B.K., S a hoo L., P a nd a S.K. Comparative effect of Ca, K, $\mathrm{Mn}$ and $\mathrm{B}$ on post-drought stress recovery in tea [Camellia sinensis (L.) O. Kuntze]. Am. J. Plant Sci., 2012, 3: 443-460 (doi: 10.4236/ajps.2012.34054).

8. Waheed A., Hamid F.S., Shah A.H., Ahmad H., Khalid A., Abbasi F.M., A h m a d N., A s l a m S., S a rw a r S. Response of different tea (Camellia sinensis L.) clones against drought stress. J. Master Environ. Sci., 2012, 3: 395-410.

9. Upadhy a a H., P a nd a S.K., D utt a B.K. $\mathrm{CaCl}_{2}$ improves post-drought recovery potential in Camellia sinensis (L) O. Kuntze. Plant Cell Rep., 2011, 30: 495-503 (doi: 10.1007/s00299-010-0958-x).

10. Mukhopadhyay M., Ghosh P.D., Mondal T.K. Effect of boron deficiency on photosynthesis and antioxidant responses of young tea [Camellia sinensis (L.) O. Kuntze] plantlets. Russ. J. Plant Physiol., 2013, 60: 633-639.

11. Pritula Z.V., A bil'fazova Yu.S. Subtropicheskoe i dekorativnoe sadovodstvo, 2004, 39(2): 427-440 (in Russ.).

12. Belous O.G. Mikroelementy na chainykh plantatsiyakh subtropikov Rossii [Microelements in the soils of tea plantation of Russian subtropics]. Krasnodar, 2006 (in Russ.).

13. N e n'k o N.I., S e rge e va N.N., K a rava eva A.V. Plodovodstvo i vinogradarstvo Yuga Rossii, 2015, 35(5): 83-94 (in Russ.).

14. G a o X.Y., Y a n g G.P., X u Z.Q., Xu F.C. Effect of calcium on antioxidant enzymes of lipid peroxidation of soy-bean leaves under water stress. J. South China Agric. Univ., 1999, 2: 58-62.

15. Shu M.Y., F a n M.Q. Effect of osmotic stress and calcium on membrane-lipid peroxidation and the activity of defense enzymes in fir seedling. Forest Res., 2000, 4: 391-396.

16. B owle r C., Fluhr B. The role of calcium and activated oxygen as signals for controlling cross-tolerance. Trends Plant Sci., 2000, 5: 241-243.

17. Li M., Van G., Li n Ts. Fiziologiya rastenii, 2004, 51(4): 575-581 (in Russ.).

18. M e d v e d e v S.S. Fiziologiya rastenii, 2005, 52(2): 282-305 (in Russ.).

19. K i m M.C. Calcium and calmodulin-mediated regulation of gene expression in plant. Mol. Plant, 2009, 2: 13-21 (doi: 10.1093/mp/ssn091).

20. S pa ld i ng E.P., H a r p e r J.F. The ins and outs of cellular $\mathrm{Ca}^{2+}$ transport. Curr. Opin. Plant Biol., 2011, 14: 715-720 (doi: 10.1016/j.pbi.2011.08.001).

21. Ols o n M.L., Chai me r s S., M c Carro $\mathrm{n}$ J.G., Mitochondrial organization and $\mathrm{Ca}^{2+}$ up take. Biochemical Society Transactions, 2012, 40: 158-167 (doi: 10.1042/BST20110705).

22. Liu H.T., Sun D.Y., Z hou R.G. Ca ${ }^{2+}$ and AtCaM3 are involved in the expression of heat shock protein gene in Arabidopsis. Plant Cell Environ., 2005, 28: 1276-1284 (doi: 10.1111/j.1365-3040.2005.01365.x). 
23. Saidi Y., Finka A., Muriset M., B ro mberg Z., We is s Y.G., Mathuis F.J., $\mathrm{G}$ o 1 o u b i n off $\mathrm{P}$. The heat shock response in moss plants is regulated by specific calcium-permeable channels in the plasma membrane. The Plant Cell, 2009, 21: 2829-2843 (doi: 10.1105/tpc.108.065318).

24. S a i d i Y., F i n k a A., G o lo u b i n off P. Heat perception and signaling in plants: a tortuous path to thermotolerance. New Phytol., 2011, 190: 556-565 (doi: 10.1111/j.14698137.2010.03571.x).

25. Rikhvanov E.G., F edose eva I.V., Pyatrikas D.V., B orovski G.B., V o i n i k o v V.K. Fiziologiya rastenii, 2014, 61(2): 155-169 (in Russ.).

26. Ryndin A.V., B elous O.G., Malyarovskaya V.I., Pritula Z.V., Abilfazova Yu.S., Kozhevnikova A.M. Physiological and biochemical approaches in studing adaptation mechanisms of subtropical, fruit and ornamental crops grown in Russian subtropics. Agricultural Biology, 2014, 3: 40-48 (doi: 10.15389/agrobiology.2014.3.40eng) (in Engl.).

27. Praktikum po fiziologii rastenii /Pod. redaktsiei I.I. Gunara [Practical text-book on plant physiology. I.I. Gunar (ed.)]. Moscow, 1972 (in Russ.).

28. Fili p p o L L.A. Vodnyi rezhim $i$ oroshenie plodovykh $i$ subtropicheskikh kul'tur $v$ gornykh usloviyakh (trudy NIIGSiTS), 1975, 21: 102-122 (in Russ.).

29. K o r milits y n A.M., M a r c h e n o N.G. Trudy Nikitskogo botanicheskogo sada, 1960, XXXII: 55-60 (in Russ.).

30. Ginzburg K.E. Pochvovedenie, 1963, 5: 89-96 (in Russ.).

31. Agrokhimicheskie metody issledovaniya pochv. Metodika /Otvetstvennyi redaktor A.V. Sokolov [Agrochemical analysis of soils - methods. A.V. Sokolov (ed.)]. Moscow, 1975.

32. Srapenyats R.A., Novikov A.I., Strebkov I.M., Shapiro L.Z., Kirik o i Ya.T. Vestnik sel'skokhozyaistvennykh nauk, 1980, 12: 34-44 (in Russ.).

33. A p e 1 K., H i r t H. Reactive oxygen species metabolism, oxidative stress, and signal transduction. Annu. Rev. Plant Soil, 2004, 55: 373-399 (doi: 10.1146/annurev.arplant.55.031903.141701).

34. B e 1 o u s O.G. Aktivnost' katalazy v list'yakh chaya $v$ zone vlazhnykh subtropikov Rossii [Catalase activity in leaves of tea plants under conditions of Russian humid subtropical area]. Saarbruchen, 2012 (in Russ.).

35. K o s h k i n E.I. Fiziologiya ustoichivosti sel'skokhozyaistvennykh kul'tur [Physiology of crop tolerance]. Moscow, 2010 (in Russ.).

36. B a c h M., S c h n i t z l e r J.P., S e i t z H.U. Elicitor-induced changes in $\mathrm{Ca}^{2+}$ influx, $\mathrm{K}^{+}$ enflux and 4-hydroxybenzoic acid synthesis in protoplasts of Daucus carota L. Plant Physiol., 1993, 103: 407-412.

37. Z y a 1 a $l$ o v A.A., G a z i z o v I.S. Fiziologiya rastenii, 1989, 36(5): 880-887 (in Russ.).

\section{Science Events \\ THE THIRD MEDITERRANEAN SYMPOSIUM ON MEDICINAL AND AROMATIC PLANTS (MESMAP-3)}

(13-16 April 2017, Girne (Kyrenia), Cyprus, Turkey)

\section{Organization: AMAPMED}

This scientific-based organization is of important forums to bring together all the stakeholders in the MAP and/or NWFP sectors. This big event welcomes the participants from all climates. MESMAP3 scientific program covers all related aspects of MAPs and NWFPs. The selected papers will also be published in a distinguished scientific journal after scientific evaluation.

\section{Contacts: http//:www.mesmap.org, mesmap2017@gmail.com}

Information: http://www.globaleventslist.elsevier.com/events/2017/04/the-third-mediterranean-symposium-on-medicinal-and-aromatic-plants-mesmap-3/ 